\title{
Kings, Viziers, Concubines
}

In the Persian/Arabic collection of fables Kalila wa-Dimna we read how a scholar is commissioned by the king to travel to India to fetch a medicinal herb. He returns after a while with the text of a book that contains a number of fables inspired by the wisdom of ancient sages. The book is not only meant to edify the general reader; it is more specifically written to enlighten the prince and help him to perform his difficult task as ruler of the empire. This tale and the text that it presents can be regarded as one of the prototypes of fictional literature: fables, that is, invented stories, have the function to educate and instruct the reader; they are not merely entertaining, but are part of the heritage of the wisdom of a community and even of the foundations of civilization. However, they do not transmit this wisdom in a direct and straightforward fashion; they rather represent their wisdom and enfold it in an entertaining and easily palatable form. The text instructs through examples, in order to appeal not only to the rationality of the reader, but also to his or her imagination.

As we will see below, this peculiar form, of a framing story containing a number of inserted tales, is not just coincidental, but conceived to support the instructive function of the text. It creates a situation of dialogues on various levels, between different layers/levels of presentation, between different layers of reality, and between a speaker and a listener. In this way the text not only opens the way to connect the process of instruction to a fictional setting; it also enacts the relationship between the reader and the narrative, giving him or her a role in the process inaugurated within the text. It is no coincidence either that the main character in the work is a king. After all, it is the king who is responsible for the welfare of the community, the preservation of social order and the continuation of the ancient traditions. It is the king who has to be initiated into the wisdom accumulated within the human tradition, not only because he has to act according to its principles, but, more pressingly, because he has to personify it. As a king he embodies the social and cultural values of the empire, and it is his duty to guard their perpetuation.

In this chapter we will examine three texts that show the king in his role as the embodiment of the values of the empire, in the face of destruction, and the dialogical nature of instruction, as a setting for a dramatic spectacle primarily staging three characters: the king, his vizier, and the royal concubine. 


\section{The Cycle of the 'Seven Viziers'/'Seven Sages of Rome' and Its Cognates}

The development of the literature of wisdom and its importance for the art of statecraft can be traced particularly in the Persian literary tradition. ${ }^{1}$ This tradition started in the Sasanid period (224-651 C.E.) and was continued after the Islamic conquest of Persia in the seventh/eighth centuries, finding expression especially in the construction and organization of rulership under the Abbasid caliphs (750-1258). The Persian tradition of this genre reached its apogee in the well-known mirrors-for-princes the Qabusnama by Kaykavus (c. 1080) and the Siyasatnama by Nizam al-Mulk (1018-1092). These texts are clearly nonfictional, although they contain exemplary anecdotes. The fictional branch of this genre found its model in the cycle of the Seven viziers, transmitted in Arabic, too, under the title The book of Sindbad, or The wiles of women. This work is the more remarkable because it not only became a famous text within Persian and Arabic literature, but also migrated to Europe, where it is known, in various languages, as The seven sages of Rome, or, in Spanish, El libro de Sendebar, and, in Latin, Dolopatos. During its peregrinations it remained remarkably stable, in terms of both its basic form and its dramatic intrigue. It thus became one of the quintessential narratives of kingship in large parts of Eurasia. ${ }^{2}$

An Arabic version of the cycle, titled the story of the 'Wiles of women', was incorporated into the later compilations of the Thousand and one nights which appeared in the eighteenth century, suggesting that at that time it still belonged to the current corpus of literature. A more sophisticated version is the Persian text by Zahiri al-Samarqandi, which was written in approximately $1160 .{ }^{3}$ The story is simple: A king governs a prospering empire, but he is old and has no son to succeed him. After praying, he begets a son, who is intelligent and virtuous, as beautiful as Yusuf/Joseph, and as perfect as Jesus. However, the astrologers predict that the boy's life will be in danger during his adolescence. For ten years, the young prince is unable to learn anything, and the sage Sindbad offers to assume the task of educating him in the proper conduct of kings, the required virtues, good manners, medicine, botany etc. He has a cubic building erected, with smooth walls on which he paints the basic principles of the various fields of knowledge: astronomy/astrology, human relationships,

1 Charles-Henri de Fouchécour, Le sage et le prince en Iran médiéval. Morale et politique dans les textes littéraires persans, IXe-XIIIe siècles (Paris, 2009).

2 See Killis Campbell, The Seven Sages of Rome, edited from the Manuscripts, with Introduction, Notes, and Glossary (Forgotten Books, 2012 [1907]).

3 Zahiri de Samarkand, Le livre des sept vizirs, trans. Dejan Bogdanović (Paris, 1975). 
diseases, music, geometry, politics, statecraft, law, and justice. After some time, the astrologers warn that according to the prophecy the prince will die if he speaks during the subsequent ten days.

For his safety, the prince is temporarily put up in the royal harem. Here a concubine of the king becomes enamoured of him and proposes to poison his father so that she can become his servant after he has acceded to the throne. The prince does not respond and the concubine, afraid that he will betray her, tears her clothes, scratches her face, and yells for help, maintaining that the prince has attacked her and threatened to kill her. Thereupon the king, infuriated, gives orders to execute the prince. Worried, the eldest vizier intervenes, arguing that the woman is deprived of reason and the boy bears the marks of righteousness, nobility, and intelligence. A rash decision, he says, will lead to regret, when repentance is too late. The assembled viziers now decide on a strategy to save the prince: Everyday one of them will tell a story to the king, in a common effort to persuade him that he should not act thoughtlessly and that he should not trust the testimony of women, who are perfidious, hypocritical, and deceitful.

During the following days the viziers and the concubine each plead their cases. The viziers emphasize the responsibility of the king, whom God has moulded as the epitome of virtue, talent, and wisdom, and who understands the hidden order of things. Being aware of this responsibility, and aspiring to a good reputation among the other kings, for whom he should be an example, he should behave in a prudent, considerate, patient, and circumspect manner, and not impulsively and in anger. He should investigate the matter and not listen to the wily and crafty claims of women. In contrast to this appeal to rationality, the concubine increasingly plays on the king's emotions. She appears before him in tears, with dishevelled hair, bent back, in desperation, pale, with her clothes in disarray, throwing dust on her head and threatening to kill herself. She accuses the viziers of disloyalty and demands a fair trial. Both sides amplify their claims by telling exemplary tales about the deceit of women or men, respectively. In the end, after ten days have passed, Sindbad leads the prince before the throne, pleading his innocence. The king, no longer overwhelmed by anger, judges him not guilty. The concubine is punished; she is shaven, her face is painted black and she is driven through the town on a black donkey preceded by a public bellman.

Compared to the Arabic version in the Thousand and one nights, summarized above, which is rather austere, Samarqandi's Persian text is much more sophisticated and accomplished. Samarqandi embeds the story in a layer of historical, moral, and religious contexts. In his prologue he invokes God and enumerates His admonishments: to heed the law, practice justice and devotion, 
uphold science and wisdom, and abstain from incorrect behaviour. Because man fears direct punishment more than the hereafter, in order to be effective prophecy requires the help of secular power. Therefore, God has strengthened religion with royalty and the state. The sultan is God's shadow on earth. He should pass his time with philosophers and sages because as soon as he delivers himself to earthly pleasures, he will neglect the affairs of the state and forget to be grateful to God. Then decay will ensue. All these claims are buttressed by quotations from the Quran. It should be noted here, that, of course, the main intrigue of the story is linked to an older, religious, tradition, the biblical story of Joseph and the wife of Potiphar, which in the Muslim-Qur'anic tradition is known as the story of Yusuf and Zulaykha. ${ }^{4}$

The Persian text of Samarqandi is probably the most elaborate and sophisticated version of the cycle. We have versions in Hebrew (thirteenth c.), Greek (eleventh c.), Spanish (1253), Latin (fifteenth c.), French (thirteenth c.), and in other European languages. These versions remained in circulation in the subsequent centuries. In all these versions, the cycle of the Seven viziers shows a remarkable consistency, retaining its form and intrigue. This suggests that its basic concept has a strong meta-cultural appeal, perhaps not only for its contents, but also because of its narrative form. After all, texts, and generic types, are not only defined by their cultural-historical context, but also have their own internal structure and textual dynamics. It seems justified to say that the cycle of the Sevenviziers is based on a concept so strongly rooted in the idea and function of narrative texts that it becomes resistant to change. The core of the cycle not only remained intact while it crossed cultural boundaries, it also became the centre of a much broader corpus of texts, which could arguably be called a genre, or a sub-genre, or a generic type, modelled after a prototypal source.

Below, we will discuss some aspects of the cycle as a generic type. 'Genre' will be defined broadly as a corpus of texts related by discursive characteristics that define an agreement between the author and the readers about the way in which the text should be situated within textual and contextual environments, that is, how it should be interpreted, how it relates to reality, and what its intended function is within these environments. For the sake of convenience, we have divided the concept of genre into three constituent components: form, fictionality, and function.

Form. The most conspicuous feature of the Seven viziers cycle is its form: It consists of a coherent framing story in which a number of separate (uncon-

4 See Shalom Goldman, The Wiles of Women, the Wiles of Men: Joseph and Potiphar's Wife in Ancient Near Eastern, Jewish, and Islamic Folklore (Albany, 1995). 
nected) stories are embedded. This literary strategy, which seems to be as old as literature itself, immediately produces certain effects and narrative dynamics, caused by a systematic differentiation between various narrative levels.

First, the framing device affects the position of the reader, since framing is essentially a multiplication of narrative levels, which suggests that the reader, too, is situated in one of the narrative levels. The effect of multiplication is not directed only inwardly, so to speak, envisioning a potentially endless proliferation of stories-within-stories; it is also directed outwardly, implicating the reader in the narrative process. Thus, the reader, too, experiences what the characters in the framing story experience when they listen to the tales told to them, enabling him or her to identify with the characters and internalize their development. If the characters are 'readers' of the inserted stories, the reader can imagine him/herself as a fictional 'character' taking part in the story.

Second, this identification through framing is connected with the creation of a dialogic situation within the text, that is, the juxtaposition of two different narrative components produced by a dialogic situation in the frame. This dialogism generates several dynamics typical for dialogues in general: It introduces the element of contingency: a dialogue may in principle continue forever, but it may also be interrupted suddenly, or steered into a specific direction, because the process of narration, within the dialogic situation, is dependent upon the reactions of the participants. The participants can manipulate the course of the dialogue by inserting threats, emotions, ingenious formulations, unexpected arguments, etc., or invent ways to either interrupt or continue a dialogue. Moreover, dialogism is always related to processes of interpretation, since it essentially confronts two different views that somehow have to be attuned to each other or at least to reveal some common ground and shared outlooks. It is a matter of contingency if, when, and how this happens, thus not only creating narrative suspense, but also introducing an element of uncertainty.

Third, the framing structure and the dialogical situation produce various forms of interaction between the different levels, such as the juxtaposition of reality with the imagination, relationships between characters within one level or between levels, the opposition of specific spaces, the use of a timeframe within the framing story, or the differentiation between temporal levels, the effect of 'doubling', both of the characters and of motifs and other textual elements, the opposition of a diegetical reality with forms of representation, etc. The splitting of levels provides the author with a whole range of devices to refine his narrative strategies.

These narrative devices are primarily elements available to the author to conceive his work, and although they are enclosed in the concept of the frame 
structure, they may not be as relevant in some cases as in others. However, they are potentially present even in quite simple texts, and may have been elaborated in complex forms within the boundaries of a genre. The 'Seven sages' is a relatively simple text in which the mechanism of the strategy of multiple levels is quite effective. This strategy not only strengthens its function as a work of instruction, but, as we will see below, also unravels the various components of kingship.

Fictionality. One of the main constituents of a generic type is the way it defines its relation to reality. Is a text explicitly fictional? Is it the author's intention to construct a realistic setting? Or, on the contrary, is it his aim to deconstruct visions of reality by uninhibitedly incorporating the 'unreal'? How does he combine realistic and fictional elements? It is, of course, not easy to define the concept of fictionality. The strategies used by the author to suggest a form of realism - such as referentiality, descriptions, dialoguesmay not be experienced by the reader as realist at all. Or, conversely, outright fictionality can certainly be interpreted by the reader as referring to a 'real' experience. These observations are further complicated when projected on premodern texts, since the boundaries between fiction and non-fiction were not clearly drawn. There is one element that seems to be inherent in fictionality, however, and that is the notion of 'dramatization', the gradual unfolding of a plot and the ordering of narrative elements to serve its construction.

As suggested in the previous section, the frame structure of the Seven viziers cycle introduces a complex configuration of realistic and fictional elements. For the reader, the element of fictionality is situated in the framing story. It is here that the initial intrigue is outlined, which is concentrated around a specific number of characteristics. The main fictional motifs are the birth of a prince and the alleged unreliability of the concubine. These motifs are dramatized by placing them in a narrative setting, distributing the development of the plot over a limited number of 'actors'. This fictional, enacted, frame represents the diegetical reality within the work, which generates not only an emplotment, but also a chain of inserted stories. These stories are presented as exemplary episodes taken from real life; they are not 'invented', but rather 'represented' by the narrators. Thus, perhaps paradoxically, although they are told by fictional characters in the narrative, for the reader, too, they retain their exemplary, realist impact. It is only the selection and interpretation of the tales that are engendered and structured by the fictional intrigue. Thus the fictional frame creates a setting, a space, for the representation of what is not fictional, not realistic, but transcending both, a fiction containing truth, a 'real' event becoming a 'model' through a process of fictionalization. 
These effects of the play with fictionality are, of course, made possible by the framing structure, with its differentiation and interaction between narrative levels. Through the use of fiction, the author can introduce new settings, new characters, new versions of roles, enabling him to reveal to the reader what is hidden for the characters; he can manipulate the sense of identification of the reader with the characters; and he can construct his discursive aims as the outcome of a narrative plot. The reader is seduced by the fictional intrigue and manipulated by both the exemplary tales and their relation to the plot, and in this way he or she completes the same trajectory as the characters in the frame, from his or her perspective from the 'outer frame'. His or her mirror image is, especially, the prince, who is educated not by mere teaching, but by pictures, images that reproduce the knowledge he is supposed to internalize.

Function. The function of the Seven viziers cycle is enacted in the plot of the framing story and can be summarized as supporting the preservation of traditional moral wisdom and explaining its importance for the government of society. The danger to the transferral of this traditional wisdom is represented as a crisis in the succession to the throne. The preservation of the dynasty, and the well-being of society, is threatened at its most vulnerable moment, when kingship has to be handed over to an inexperienced prince. The dangers are represented by the apparent ignorance of the prince and the viciousness and treachery of women. The real threat, however, is in the response of the king to these dangers: if he acts unwisely, the continuation of the dynasty and governance will be in danger; if he heeds traditional wisdom, the dynasty will be saved. It is thus first of all the king to whom the admonitions are directed.

The function of the work is effectuated through its form and fictionality. First, the frame structure can introduce a strategy of temporalization, in which two layers of the dilemma are exhibited: the singular case of the prince and the queen is juxtaposed to a number of examples from real life, linking the specific case to what gradually becomes a model. In this way, the problem at hand is rationalized and objectified, transformed from a specific case into a general phenomenon. The evil concubine step by step becomes 'woman' in general. This 'layering' of the problem through representing it in various ways in 'abstract' stories has the function to deconstruct the superficial, evident nature of the conflict and represent it in other forms, with other actors, from other perspectives, thereby splitting up the narrative construction of the conflict into various aspects, looking at a multiformity of explanations and fostering a distant, abstracted view of the underlying causes. In this way, the conflict can be redefined and its various representations can be reinterpreted. 
The formal component is supported by the fictional component, because the enactment of the story through roles and a plot introduces the element of dialogism. The king, the viziers, and the concubine each represent different aspects of the conflict, which cannot at first sight be reconciled. By having these aspects explained in the inserted stories, they are objectified and explored, and in the process the different perspectives are compared and judged, resulting in a common ground, a shared perspective, which makes consensus and a solution possible. Moreover, the characters are representations of figures in society, with their connotations, roles, and properties. They are allegories or symbols related to the crucial mechanisms of social structuring and reproduction, and the fundamental constituents of a social order. Their roles are supplementary but also contradictory, and their interaction reveals tensions and potential harmonies.

The generic components of the work thus enable the characters and the reader to link the specific case to the mechanisms of society and the system of traditional wisdom, which holds that in cases of conflict a king should not act on impulse, but rather look at the case from different perspectives and take time for deliberation. But why is this so vital? This deliberation is necessary not only because it is a matter of life and death to separate the lie from the truth and find out the true facts of the case; it is also necessary because the whole construction of the conflict is embedded in a framework of huge differences of power. The king is, of course, all-powerful, and the prince and the concubine are vulnerable subjects delivered to his arbitrary decisions. However, the power of the king is based not only on his ability to act according to his will on specific occasions; it is also vested in the tradition of kingship and in the authority derived from it. Therefore, there must be some form of mediation to protect the weak actors from the direct, formidable, power of the king and to accommodate the power of the king to a form of authority and responsibility stabilized by tradition. Thus, again, the preservation of traditional values and the principles of justice is based on a transformation of a particular incident into a general system.

In the end, all problems are solved. The truth of the contradicting testimonies is established, the prince has acquired the knowledge and wisdom he needs for succeeding to the throne, and the evil concubine is punished. And, most importantly, the threat to the continuation of the kingship is neutralized and the cycle of the dynasty is restored. Kingship has been preserved as an institution, by accommodating the impulsive inclinations of the king to the broader system that defines authority and justice, and that uses procedures to discover the truth. The severity of the conflict has brought to light the structural elements of a tradition, which are now incorporated in a work that not 
only presents them but perpetuates them. Not only do the king, the prince and their empire profit from this outcome, but the reader does as well.

To conclude this brief discussion of the Seven viziers cycle, we can say, first, that the cycle shows the essence of the institutionalization of authority, the transformation of power into authority, the application of justice through rational evaluation, the suppression of emotional impulses, and the compliance with traditional wisdom; the procedure for solving conflicts, by an almost ritual inventorization of testimonies, resulting in objectifying a singular incident into general principles. Second, the cycle shows the essence of the function of literature, which is needed to find a form to present the stable core of the tradition by combining aesthetic and didactic components, using emplotment, narrative strategies, fictional elements, formal techniques, the dynamics of dialogism, and forms of dramatization. Third, the cycle shows the relationship between narrative texts and reality, not only indicating that the behaviour of people and the relationships between people are structured by narratives, but also that narratives can intervene in the real course of events. What is imagined, what is narrated, what is spoken, and what is laid down in texts are capable of both disrupting and re-stabilizing the lives of individuals and societies. Narration is the main strategy against irrationality, chaos, and the disruptive force of lies. It is this fundamental purport of the 'Seven viziers' cycle that makes its main pattern so resistant to change.

The 'Seven viziers' cycle thus represents a basic form of the literature of the fictional mirror-for-princes type, establishing the main characteristics, motifs, and form that determine its function in discourse and society. We will encounter this basic pattern in many of the texts discussed below. It exemplifies the principle of dialogism, which is not only meant to facilitate the process of instruction, but also shows that, although the king is the personification of the values and morality of civilized society, he is nevertheless not a monolithic figure. He is, as a phenomenon, of a composite nature, acting in symbiosis with his viziers. He is a human being who is prone to impulses and emotions, and has to be guided by others. Moreover, the principle of dialogism acknowledges the essential contingency of events and decisions, while at the same time suggesting a way to deal with it. The outcome is never certain, but can be deferred and moulded by the use of reason.

The whole process of deliberation and instruction is instigated by the rupture that threatens the kingdom because at first the king has no son and subsequently the prince is almost executed. This motif is omnipresent in narratives about kingship, since the moment of succession is the vital event in the concept of kingship; the moment in which its continuity is determined and its foundations are re-invented and revitalized. This process requires a thorough 
initiation of the prince into the principles of kingship, statecraft, and human nature. In this respect, too, the 'Seven viziers' cycle presents one of the narrative elements that will recur in our discussion: the motif of initiation.

The story firmly posits the role of the vizier, as the guardian of tradition and wisdom and as the exponent of reason. Being the all-powerful ruler, the king is obliged to show his might, even by expressing his anger and acting impulsively. It is the task of the vizier to protect him and the subject from the king's inevitable wrath, redirecting it to its normal channels of power exertion. The vizier is indispensable as a stabilizing element in the idea of kingship. Since the nature of arbitrary power demands intimidation and the threat of violence, it is his task to soothe the king's wrath and restore the process of deliberation. Conversely, women are seen as the quintessence of instability and unreason. They are the personification of irrationality, emotionality, rashness, deceit, lust, and disorder. They threaten the established order by penetrating into it through deceit and manipulation, affecting the judgement of the king by arousing his emotions rather than his mind, undermining his awareness of the principles underlying his authority. Women are thus the antithesis of the vizier, the force that permanently endangers the survival of the empire.

The crucial element in the cycle described above is the act of narration. It exemplifies how realism and fiction are not contradictory but rather complementary as a means to understand events and interpret them. In a sense, fictionality contains more truth than reality, because it is abstract and therefore not linked to a specific, concrete, situation. Through fictionalization the essence underlying an event can be made clear, thus laying bare the general rule as opposed to an incidental, unique, response. Ultimately, the magic word in this type of discourse is 'reason', a term that has stability, patience, prudence, judgement, equilibrium, examination, consideration, etc. as its connotations, and that, as a single principle, is a precondition not only for turning power into authority, but also for ensuring harmony in the empire and in the relationship between the king and his subjects. Reason is not confined to a specific context or dilemma; it is the essence securing the preservation of the tradition that protects society. In Samarqandi's version, the principle of reason is connected with the prescriptions by God expressed in the religious tradition. The legitimacy of worldly power lies in the decree by God that man is in need of leadership, supplementing the divine revelation and overseeing the implementation of its regulations. 


\section{Variations: The Story of 'Jali'ad of Hind and His Vizier Shimas'}

To see how these basic elements can be reconfigured in new narratives in which the principles of kingship are further developed, we will now turn to an interesting story that appears, in Arabic, in the eighteenth-century versions of the Thousand and one nights, but that seems to have Persian roots. In the story of 'Jali'ad of Hind and his vizier Shimas' we meet the familiar motif of a mighty king of a prosperous empire, who is just and compassionate, and provides safety, prosperity, peace of mind, and low taxes for his subjects, but who has no son. Then, in a dream, the birth of a son is announced, who will inherit the throne but will become a tyrant and an oppressor. When the son is born, the celebrations are attended by scholars, philosophers, writers, and physicians, and the viziers. The most brilliant of the viziers is Shimas, who is twenty-two years old, but wise and well educated. When the prince, named Wirdkhan, is seventeen years old, his father dies after giving him wise advice, and he ascends the throne. ${ }^{5}$

In spite of his father's exhortations, soon the young king falls prey to his carnal lusts and perverse desires. He collects beautiful women in his harem and withdraws with them in their compounds, neglecting the administration of the empire and the complaints of the subjects. Shimas, worried, tries to persuade him to change his ways, arguing that a king should spend only two hours a day with his women, to avoid harm to the body and the mind. Many kings have come under the influence of women, who are known for their bad advice. Wirdkhan's women, however, succeed in convincing him that his viziers only want to mislead him, one of them saying: 'The king's subjects are his slaves, but now I see that, king though you are, you are the slave of your subjects in your awe of them. [...] If they find that you are weak, they will despise you, whereas if they see that you are courageous, they will respect you.' ${ }^{6}$ And: 'There is a saying that no one whose heart is not hard as iron is fit to be a king. It is your clemency that has led these people astray so that they have had the impudence to cast off their allegiance to you, although they should be compelled to submit and forced into obedience. ${ }^{7}$

Gradually, the discontent turns into outright revolt. The people want to dethrone the king, and the notables storm the palace. The king's concubine

5 For a summary of this story, comments and references, see Marzolph and Van Leeuwen, The Arabian Nights Encyclopedia; The Arabian Nights: Tales of 1001 Nights, trans. Malcolm C. Lyons and Ursula Lyons, 3 vols. (London, 2008) vol. 3, 439-519, 899-930.

6 The Arabian Nights, vol. 3, 490 .

7 Ibid., 495 . 
now thinks up a ruse: One by one the viziers are asked to enter the king's room for consultation and are subsequently killed on the spot. Now the king can freely enjoy his carnal pleasures, while abuse of power and oppression are rampant throughout the empire. The king of the adjacent empire hears about the mishaps of his neighbours and sends a letter declaring war. Wirdkhan, desperate, asks the advice of his women, but they say: 'Women's wiles don't work when it comes to war. They have neither judgement nor strength, as these, together with stratagems, are the prerogatives of men in cases like these.' Wirdkhan starts roaming the city and suddenly, by coincidence, finds the young son of Shimas. When begged to help the king, the boy answers that he should ask the advice of his women, but now Wirdkhan says: 'Boy, I acted out of folly, but the plans and schemes of women are very evil', referring to the well-known Qur'anic verse (chapter 12, verse 28). ${ }^{9}$ Subsequently, Shimas's son is installed as the new vizier, the hostile king is bluffed away by his wisdom, and the danger of war is averted.

Shimas's son takes this auspicious opportunity to teach the king a lesson: 'Your majesty, you should know that [the cause of your sins] was your love of women, your attraction to them and the fact that you accepted their advice and fell in with their plans. Love of women alters the pure light of reason and corrupts a sound nature. ${ }^{10}$ Wirdkhan argues that the women were responsible for Shimas's death: 'That was not something that I wanted and I cannot understand how I came to agree with them to have it done'11 The young vizier retorts: 'Almighty God, Who created us, granted us the ability and free will with which to make our choices, so that we only act if we wish to do so, and not if we do not.'12 The empire is put in order, and the women are imprisoned in the room of the executions and starved to death.

Like the cycle of the 'Seven viziers', the story of 'King Jaliad' is also meant as the enactment of an intrigue, which facilitates a rich display of the traditional wisdom about kingship. The story is interspersed with exemplary tales, which give the viziers the opportunity to philosophize about the nature of kingship and its positive characteristics:

It is [God] Who grants kingship and rule throughout the lands to those whom He wishes from among His servants, picking those He wants to

\begin{tabular}{ll}
\hline 8 & Ibid., 50o. \\
9 & Ibid., 506. \\
10 & Ibid., 513. \\
11 & Ibid., 514. \\
12 & Ibid.
\end{tabular}


stand in His place, acting as His deputies among His creation. He orders these rulers to behave with justice and equity, establishing the laws and customs of religion and acting rightly and properly in the affairs of their subjects in accordance with His wishes and theirs. ${ }^{13}$

\section{A king should be}

intelligent, a master of all branches of learning, the rules of governance and administration, pure in his intentions and treating his subjects with justice. He must show honour and respect when it is due and, when he is in a position of power, he should display clemency where it is necessary. He must look after the interests of both governors and the governed, lightening their burdens, giving them favours, refraining from shedding their blood, attending to their needs and keeping his promises to them. ${ }^{14}$

Such a king protects the empire against enemies and is wise, just, compassionate, and generous to the poor. He is loved by his subjects, enjoys esteem among the other kings, and is blessed with God's benevolence. As long as a king possesses all these virtues, the empire will prosper, the enemies will be defeated, and catastrophes will not occur.

The conditions of good kingship are explicitly expounded when Wirdkhan's education is tested. When the young prince is twelve years old, a palace with 360 rooms is built for him, each dedicated to one of the sciences. Every day the prince enters a new room to be taught new knowledge by scholars. After one year his progress is tested by an examination. First, the admonitions against indulgence in earthly affairs are reiterated: 'Who delivers himself to the scarce pleasures in the world will perish, because he prefers earthly life above the hereafter. [...] Whoever seeks a livelihood in this world should not let any day pass without looking towards the next world,' because 'body and soul share the same rewards and punishments. ${ }^{\prime 15} \mathrm{~A}$ king with sound judgement and a clear mind will not be affected by lust and desire. He must keep his base inclinations under control. Here, again, we find the basic message of the story, and of the genre as a whole: The king must act rationally and not impulsively; the desire for women is the greatest threat to the survival of the empire.

\begin{tabular}{ll}
\hline 13 & Ibid., 459. \\
14 & Ibid., 452. \\
15 & Ibid., 464-465.
\end{tabular}


Next, the relationship between the vizier and the king is discussed. First, the hierarchic authority is defined: '[The king's] authority over you is confined to the duty that you owe him, and if you give him this, he has no further power over you. ${ }^{16}$ Second, the tasks of the vizier are explained: 'Advice, diligence both in private and public, sound judgement and the keeping of secrets. [...] The vizier must not hide from his king anything that the king should know and he should not neglect to carry out whatever has been entrusted to him, while trying to please his master in whatever way possible without angering him. ${ }^{17} \mathrm{He}$ has to behave with reverence, but, if necessary, he should correct him: 'It is his duty to point out the way of justice and fairness, cautioning against injustice and oppression while instructing his master how to treat his subjects well. [...] If the king listens and accepts this, the vizier will have achieved his object, but if he does not, the vizier's only recourse will be amicable separation, as this will bring relief to both of them.'18 The people should respect the vizier, who will protect them against harm.

Finally, the attitude of the king towards his subjects is explained, which should be in accordance with the wishes of God. The king should protect their possessions and women and show magnanimity in exchange for obedience. The king has three duties: the defence of religion; the protection of the subjects; and the safeguarding of the affairs of the state. He should preserve customs; appoint scholars and sages for education; settle disputes; guard the purity of blood; protect properties; avoid heavy taxation; and strengthen the army. Finally, 'the rights owed by the king to his subjects are more binding than those that they owe to him, in that a failure on his part to respect what they are owed is more destructive than the reverse. It is only because of such a failure on the king's part that he will face destruction, together with the loss of his realm and his prosperity. ${ }^{\prime} 19$

The story of 'Jali'ad of Hind and his vizier Shimas' clearly shows the hybridity of the genre to which it belongs, partly conforming to the type of the mirrorfor-princes, and partly to a cycle of exemplary tales. It bears resemblance to, for instance, the story of 'Tawaddud', which is transmitted in the Thousand and one nights, but also as a separate story, and also to an episode in the epic story of 'King Umar al-Nu'man', in which princess Qudiya Fakan displays her knowledge. In these stories, however, the intrigue is reduced to a minimum. Conversely, a cycle more related to storytelling than to instructive works, but

\begin{tabular}{ll}
\hline 16 & Ibid., 468. \\
17 & Ibid. \\
18 & Ibid., 470. \\
19 & Ibid.
\end{tabular}


which is built around similar dramatic intrigues, is the story of 'Azadbakht', or 'The ten viziers'. The plot is slightly different here, because it is the viziers who are the instigators of evil. This cycle was translated by Richard Burton in his Supplemental nights, but it was already known in Europe through the version in the manuscript compiled by Dom Chavis, which was translated and revised in co-operation with the French writer Jacques Cazotte (1785). A translation of a Turkish version was published by Comte de Caylus in his Nouveaux contes arabes (1788), and an English version by Robert Heron appeared in Edinburgh in 1792. In Arabic it was published in the Breslau edition of the Thousand and one nights, and in the partial texts edited by Caussin de Perceval, Gautier, and Ouseley. The story was probably of Persian origin and translated into Arabic and, because apparently it still circulated in Ottoman times, translated into Turkish in the sixteenth century. All these cycles, which were popular across cultural boundaries, are built around the stereotype of the vicious concubine, the initiation of the prince and the inherent contradictions of kingship. This brief survey shows how the generic type of the cycle of the 'Seven viziers', with its peculiar form, survived not only the vicissitudes of time, but also the transition between various cultural domains.

\section{King Wu's Expedition against Zhou and Proclaiming Harmony}

The cycle of the Seven viziers and its cognates give us insight into the narrative strategies used to convey a specific philosophy of kingship based on tradition and religion, and the motifs that form the crucial links between the fictional and non-fictional components. We will now continue to examine the occurrence of these motifs in another tradition of literature and kingship, and in a more novelistic type of narrative. In the Chinese tradition we find similar motifs in narratives that, in this case too, are hybrid, not because they combine instructive and fictional elements, but because they consist of a mixture of historical and fictional elements. The ultimate aim is similar: to show how the moral integrity of the king affects the prosperity of the empire.

As in the case of the Persian/Arabic wisdom literature, Chinese concepts of moral conduct and social order can be traced far back in history. Over the course of centuries, three main philosophical systems developed into the main framework for Chinese thought and shaped visions of life and the world: Confucianism, Taoism, and Buddhism. Although these systems have remained significant, as a framework for morality, until the present day, they have not been resistant to change. They were not isolated from historical circumstances, which instigated them to develop new trends of interpretation, fostering or 
repressing their spread, connecting them with or disconnecting them from state interests, etc. Thus, Buddhism witnessed its emergence, its heyday, and its-relative-decline; Confucianism and Taoism took shape within various schools, which were supported by a steadily growing corpus of texts and interpretations; periods of fundamentalism alternated with more liberal trends. So although the three philosophies never lost their importance as a frame of reference, they were not monolithic or stagnant. They provided principles that could be elaborated, but that could also be referred to in their 'pure' form.

The Chinese philosophy of statecraft emerged within this ancient tradition of thought. One of the earliest expressions of this philosophy is to be found in the essays written by Prince Han Feizi, who lived in the Qin Empire in the third century B.C., which represented an important phase in the unification of China as an empire. Although Han Feizi never reigned himself, he left a compendium of instructions for the ruler, which is considered as belonging to the corpus of the so-called Legalist School, a group of scholars who aimed to systematize the basic rules of government in a framework of rational thought. Han Feizis compendium is the main work remaining from this School, and although it is concise, it retained its importance through the ages. It should be noted that the work dates from before the great unified empires, with their almost celestial visions of the emperor. The book does not refer to religion or the divine status of emperors, but rather provides a pragmatic set of instructions to foster the smooth execution of government. Although it is less rigorous, it can be compared to Machiavelli's Il principe, which is also concerned with the mechanisms of power, rather than with the theoretical underpinnings of sovereignty.

Han Feizi's main concern in his treatise is not the status of the king, but rather his functioning within the apparatus of government. In accordance with Tao, the emperor is not actively engaged in ruling and commanding; he is rather the embodiment of the order in which the state apparatus functions, and the medium that makes its functioning possible. He represents order rather than installing it and only has to guard the proper functioning of all components of the state. The basic tasks of the state are, first, the securing of sufficient revenues to enable it to efficiently exert power; and, second, the strengthening of the army to support the authority of the sovereign. The basic principle of the organization of the state is rationality, that is, judgement solely based on the examination of evidence and upholding a uniform set of laws, which replaces the multifarious system of customs, inherited rights, and privileges of the previous regimes. It is, of course, this latter principle from which the school obtained its denomination of 'Legalists'. It marked the beginnings of legal philosophy in China, which remained influential throughout the centuries. 
In his book about statecraft, Han Feizi discusses diplomacy, economy, war, and administration on a very practical level, depicting the behaviour of the prince and his relationship with various functionaries. He is exhorted to systematize the organization of functions and tasks, defining and distributing them according to strict and fixed regulations, constantly comparing the formal tasks with the results of their execution. Since the regulations are clear and unambiguous, evaluation is not subjective, depending on human judgement, but objective, based on facts recorded in written reports. In this way the merits of all functionaries can be assessed. A system should be introduced in which written accounts, reports, inventories, calculations etc. are essential, because it is the effectiveness of the results that counts. This implies that not the individuals but the system prevails and that the emperor's task is limited to the installation of the institutions, regulations, and principles that safeguard objectivity. He should instate a natural order from which he can more or less remain absent.

The 'objectification' of the state functions is one of the main concerns for Han Feizi, because it is here that he sees the main threat to the proper functioning of the government. The greatest danger to the position of the emperor is the appointment of disloyal and corrupt officials. These not only take bribes, falsify reports, and build a clientele of loyal subordinates; they are also prone to undermining the authority of the emperor by creating their own power base within the state apparatus. By doing this, they not only weaken the position of the emperor, but also disrupt the functioning of the government and spread their corruptive evil to all segments of society. This will lead to a decline in agriculture, the fragmentation of the army, the collapse of the legal system, and, ultimately, the incentive for foreign foes to invade the empire and destroy the dynasty. To avoid this calamity, the emperor should always carefully select his ministers and insist on the meticulous execution of the tasks linked to specific functions and ranks. He should behave in a very reserved manner, so as not to disclose his true feelings and preferences, and he must examine the reports of the bureaucracy and be rational and consistent in his rewards and punishments. Most important of all, he should monopolize the granting of rewards and punishment to prevent the ministers from appropriating responsibilities that would enable them to carve out an independent power base.

As is clear from the above, the legalist system is founded on rationality and objectivity to such an extent that human inclinations and subjective preferences within the state apparatus should be considered as an immediate threat to the empire as a whole. Han Feizi emphatically warns the proto-emperor not to cultivate an affection for singing-girls, because this would obscure his judgement. Passion is here, as in the cases discussed above, presented as a destructive 
force, which should be controlled and suppressed. How passions can cause the destruction of the empire is one of main themes in Chinese literature in its various phases. An early example is the short novel King Wu's expedition against Zhou, by an unknown author and probably datable to the beginning of the fourteenth century. It describes the collapse of the Shang dynasty, which was replaced by the Zhou Empire in 1066 в.C. According to the translator, it is a rather rough narrative, not very sophisticated, taken from what probably was a storyteller's manuscript. ${ }^{20}$

The novel opens with a brief recapitulation of the descent of the main character of the story, King Zhou, who was the last ruler of the Shang dynasty. The story begins like a chronicle, summarizing the forefathers of King Zhou, who is briefly typified as a king who led a 'voluptuous' life; the state affairs were decided during orgies, and hence the state was not peaceful and war ensued. Nevertheless, as a man King Zhou was a genius: He knew the works of hundreds of classical authors; he was able to count sheep without making mistakes; he could defend himself against a thousand men and drink a thousand cups of wine; he had a deep, loud voice, and his handwriting followed the 'Pa-Fên' style; he was forty-seven years old, handled heavy boughs and wild horses with ease, and subdued the barbarous tribes. At first his kingdom was well organized, with a Great Admonishing Minister, a Court Adviser, a Great Marshal, a First Military Governor, an Officer Administering the Court, and eight Earls who were the pillars of his power. Every year a libation ritual was performed before portraits of his predecessors in the presence of the Earls.

On an ominous day the king joins his spouse for a visit to the Jade-Maiden Temple. During the ceremony he sees the clay statue of the fairy goddess who is a 'damsel of unique beauty'. The king is deeply struck by her beauty and at night has a dream in which she hands him a sash and promises to meet him after hundred days. In the morning he realizes it was just a dream, but he still has the sash. To assuage his desire, he gives an order to collect the most beautiful girls of the kingdom to select a new concubine. One of the candidates is Daiji, the daughter of an official. While she is sleeping, the night before the audience, she is approached by a 'nine-tailed and golden-haired' fox-spirit, who 'drew away air from the nostrils of the girl as well as her marrow. Then the body of the girl was empty and very thin. The fox then blew air into the body, thus changing the soul of the girl, making her bewitching. ${ }^{21}$ The girl, thus turned into a fox-

\footnotetext{
20 Wu wang fa chou p'ing-hua, in: Liu Ts'un-yan, Buddhist and Taoist Influences on Chinese novels, vol. 1, The Authorship of the Feng Shen Yen I (Wiesbaden, 1962) v-vi.

21 Ibid., 11-15.
} 
spirit, is of indescribable beauty, and inevitably she is chosen by the king as his new favourite.

From the moment Daiji enters the palace she imposes her will on everyone. She has the Jade-Maiden Temple destroyed out of jealousy and orders the construction of sumptuous palaces. The Earls and the Ministers are shocked and try to persuade the king to abandon the ambitious building plans:

My lord, why do not you follow the good example of Yao and Shun, and have a peaceful world? Shun set a good example in promoting filial piety to other nations, and Yü is credited with control over the floods, helping thousands and thousands of people to escape calamity. [...] Listening to Daiji will bring ruin to our country and our families and the people will suffer. ${ }^{22}$

Daiji threatens to lock herself up and die if the king obstructs her plans, and the palaces are built in spite of the protests of the Ministers. Earl Ji Chang predicts that the immoral, voluptuous life of the king will destroy the nation, as has often happened in the past. He mentions the example of King Jie, who 'enjoyed himself amid beauties and with what we call mountains of meat and pools of wine. He caused naked boys to play licentiously with nude virgins. He lost the country because he was ruthless. ${ }^{23} \mathrm{He}$ wasted money on building projects while the people became impoverished and destitute. The Earl is punished for his comments.

The unrest at the court is exploited by the corrupt minister Fei Zhong, who concocts a plot to strengthen Daijis position. She is to visit the queen, hide a dagger in her (the queen's) robe and hurry out of the room with dishevelled hair, screaming that the queen attacked her and threatened to kill her. The scheme is successful: The queen is thrown from the Star-Plucking Building and dies, and all her maids are killed by being drowned in the wine pond or by being cast in the serpent cauldron, which is filled with snakes, lizards, and scorpions. The nurse of the young prince survives and tells the lad what has happened. Daiji now says that the prince has hit her, and he is condemned to death. Before he is executed, however, he is snatched away by a mysterious man.

The outrageous schemes of Daiji trigger a revolt by the righteous faction of the Earls and the administrators. The revolt is initiated by the prince, who wants to collect an army to dethrone the king. A coalition is formed, which acts

22 Ibid., 19.

23 Ibid., 21. 
as a kind of counter-kingdom, where forces of revolt gather under the good and just leadership of Ji Chang and later his son $\mathrm{Wu}$, and against the clique of the traitorous Fei Zhong. After fierce fighting, the capital of Zhou is conquered and the king and Daiji are decapitated.

This brief summary shows that, as in the case of 'King Jali'ad', the novel about the downfall of King Zhou is made up of elements from different genres. It is first of all presented as a historical account, referring to historical figures, a historical episode, and information gleaned from historical sources. The historical dimension, shaped by some formal and stylistic strategies, such as the chronological summary and the list of state functions, provinces, etc., is clearly intended to add to the suggestion of authenticity and realism, strengthening the message conveyed by the story as rooted in historical truth. Because it cites examples from the past as significant lessons for the future, it positions itself within the reservoir of historical exempla, which together illustrate an essential truth, in the moral and the political senses. Still, history itself mainly records events without explaining them. To make history and the lessons it contains comprehensible, some new element has to be added that gives insight into psychological motivations or the intervention of outside forces. In itself history is stable and self-reproductive, so how can decline have set in?

In order to squeeze the meaning of historical events out of straightforward chronological accounts, a fictional element has to be added, in this case represented by the episode of the Jade Maiden and the metamorphosis of Daiji. This episode explains to the reader how the seemingly sensible and just King Zhou, presented as the strong pivot of the empire, became affected by passions and thereby caused the weakening of the state structure and the moral fibre of the empire. The intrigue is set in motion by an impropriety, in this case the desire of the king for the Jade-Maiden statue, which unleashed the intervention of supernatural forces in the form of the fox-spirit taking possession of Daiji. This brings the supernatural element into the historical process, as an intruding force disturbing the regular order of things. It immediately evokes supernatural counter-forces, such as an enchanted sword and a magic bracelet that deter demons and the prince who is born from a female corpse in a grave and who later, with a divine axe that only he can handle, helps to defeat the evil king and his concubine.

A remarkable episode, linking the story to supernatural forces and even the hidden forces of fate, involves Earl Ji Chang, who at the beginning of the revolt hands himself over to King Zhou and is imprisoned. He tells his sons that they should come to rescue him after seven years, because only then will the ruthless king be chased away. When one of his sons arrives after seven years, he is killed by the king and served as food to Ji Chang. After this awkward meal, 


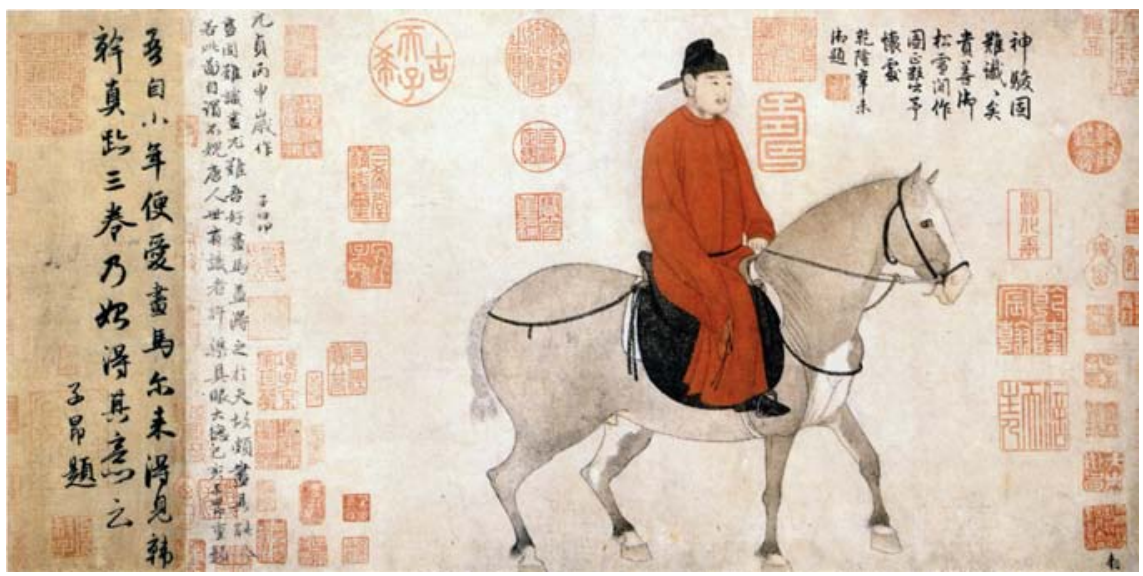

FIGURE 2 Mounted official, China, 1296.

Ji Chang is set free and becomes the leader of the rebels. This episode is not merely a fictional element inserted to conjure the supernatural forces who have caused the evil turn of events; it is also a means to link the story to a tradition with a strongly moral content. This is indicated by the references to Zhou's predecessor King Tang, who is mentioned in the beginning as an example of a virtuous king. After being invited three times to ascend the throne, he finally complied, put an end to cruelties, and organized the empire according to auspicious signs. After some time, a period of starvation set in. The king prayed for rain, but the Grand Historiographer said that a man should be burned and dedicated to God. Subsequently, without hesitation, the king had a pyre built in the mulberry wood and was burned together with his queen and their son. Immediately rain started to fall. This (pseudo-)historical anecdote, together with the reference to the lascivious King Jie and Ji Chang's self-sacrifice, reveals how personal virtues and moral strength can change the course of history, because they are linked to the cosmic harmony that ensures the welfare of the kingdom. The virtuous Ji Chang becomes the ruler of a rivalling kingdom, and his son Wu not only succeeds him but also defeats King Zhou and takes his throne: the cosmic order is restored.

Apart from the combination of historical and fictional elements, which serves as a catalyst to reveal the moral layer of history hidden underneath the events, the novel also displays some significant principles of statecraft. First, the reign of Tang is referred to, which is later mentioned again as an example of righteous kingship; second, the capacities of King Zhou and the early organization of his kingdom are described; third, when events take an ominous turn, the Earl and Ministers warn the king by referring to good- 
and bad-examples from the past and general principles of administration. And, finally, the notion of good administration is linked to the figure of Earl Ji Chang, the first official to admonish the king, and the commander of the rebels who set up a rivalling rule. Among the tenets marking Ji Chang's rule is that the people should not be oppressed, because they 'are the basis of a nation and depend on the nation'. ${ }^{24}$ His administration is based on care for the miserable and the solitary, the advancement in office of men of talent and virtue, the optimal use of manpower, and the king's sharing his soldiers' suffering and pleasure. ${ }^{25}$ These principles, based on acknowledgement of the rights of the people and of the danger of corrupt officials, together with moral integrity, are the solid foundations of the enduring state. Below, in our discussion of the novel Creation of the gods, which is based on the same story, we will see how these principles are connected with the overarching celestial forces.

\section{Proclaiming Harmony}

The principles of kingship expounded in King Wu's expedition are confirmed and supplemented in a remarkable novel titled Proclaiming harmony, which is also a vernacular romance written by an unknown author, probably in the first half of the fourteenth century. This novel is also an account of historical events and based on historical sources-even incorporating passages from chronicles. It relates the final days of the Northern Song dynasty (96o-1127 C.E.), when the last emperor of the dynasty was deposed by the invading Jürchen tribes from Mongolia, who established the Jin dynasty in 1126. It covers the period 10691124, comprising the appointment of Wang Anshi as Grand Counsellor, the fall of the Song capital, and the abduction of the royal family to the north, followed by the foundation of the second Song dynasty under Kang (Gaozong) in the southern capital Hangzhou. The novel was very popular in the sixteenth century, but was banned around 1700 by the Manchu rulers because of its antiMongol bias. The second part of the story gives a lively and detailed description of the suffering of the emperor during his abduction by the nomads, and thereby supplements the novel Yue Fei, which we will discuss in Chapter Three. ${ }^{26}$

The story of Proclaiming harmony begins with a general statement of the forces determining history and linking it to the basic principles of the universe:

\footnotetext{
24 Ibid., 37.

25 Ibid., 37, 44, 59.

26 See for the historical context: F.W. Mote, Imperial China 9oo-180o (Cambridge, MA, 1999) $206 \mathrm{ff}$.
} 
'These two patterns, of order and disorder, are merely part of the pattern of Yin and Yang. China, the enlightened man, and the great order of Heaven all belong to Yang. The tribes, petty man, human lusts - these all belong to Yin.'27 If Yang is in the ascendant China will be tranquil, the ruler will be enlightened, and the empire will be at peace and fertile; if Yin is dominant, the tribes will rule, selfish men will be promoted, and hunger and discord will reign. 'This alternation of Yin and Yang all depends upon good or evil intentions of one man - the emperor. ${ }^{28}$ Subsequently, the story itself is picked up with, first, a prediction that a Southerner will be employed who will bring great disturbances to the empire. This ominous figure is Wang Anshi, who 'makes wickedness look like loyalty and calumny look like truth. He maintains an outward appearance of ingeniousness; yet in his heart he is a conniver.'29 After his appointment he immediately starts to nominate his son-in-law and his son-in-law's brother to important offices and to scheme against his rivals. He 'ruins honest officials, conspires with scoundrels, spreads vicious rumours, cheats the emperor, and mistreats the people. ${ }^{30}$ To make things worse, he ushers in a period of reforms called the New Laws.

After five years the emperor dies and the new emperor Huizong accedes to the throne. He is described as very talented: He is a painter and a calligrapher, and he is well versed in the Three Teachings and the Nine Schools. However, he is inclined to 'trifling amusements and sensual pleasures. ${ }^{31} \mathrm{He}$ loves exotic flowers and animals and curious rocks. Moreover, he allows his minister to embark on enormous public works and the construction of luxurious palaces. In the course of time, he comes under the influence of a Taoist sage and becomes increasingly immersed in religion. He limits the influence of Buddhism and encourages the study and practice of Taoism, swelling the numbers of Taoist priests. He becomes engaged in superstitious practices. As a result of his neglect of state affairs, the evil officials can do as they please; they close the imperial factories, dismissing thousands of workers, and force generals and soldiers to form bands of robbers. They invite sycophants to the court and encourage the emperor to indulge in useless pastimes.

In a crucial episode in the novel, the emperor, at the instigation of his ministers, agrees to go on licentious excursions in the less reputable streets of the

$\begin{array}{ll}27 & \text { Proclaiming Harmony, trans. William O. Hennessey (Ann Arbor, 1981) } 3 . \\ 28 & \text { Ibid., } 4 . \\ 29 & \text { Ibid., } 11 . \\ 30 & \text { Ibid., } 13 . \\ 31 & \text { Ibid., } 14 .\end{array}$ 
capital, dressed as a common subject: 'He hastily doffed his dragon robes and slipped into a black sack, a purple doublet with red silk knotted tassel turban, and black boots. They sneaked out of the rear gate of the Forbidden City.'32 In the street of the most famous courtesans of the capital, he 'inadvertently' catches a glimpse of a beautiful lady, 'a maiden with clouds of raven hair styled with golden phoenix combs. Her eyes sent glances like glittering autumn waves beneath brows as dark as the hills in spring. Her waist was pliant like a willow, and her flesh was creamy white. She had long and slender fingers like shoots of spring bamboos and exquisitely firm and tiny bound feet.'33 The emperor is immediately infatuated with her and sleeps with her. The courtesan is Li Shishi, who already has a lover, who, not unexpectedly, is angry at her. Nevertheless, the emperor cannot resist the temptation of Li Shishi's beauty and starts paying her regular visits. Her lover becomes a nuisance and threatens to create a scandal about the emperor. Still, in spite of the warnings of some faithful ministers, the emperor settles Li Shishi in the palace and has her sit next to him on the throne.

Instead of restoring some kind of order, the new arrangement accelerates the fall of the empire. The queen, inconsolable, predicts a bad outcome: 'The three bonds of family and the five constant virtues are being dragged to the ground. When men have a sense of decorum they are strong; having it not, they are destroyed. ${ }^{34}$ At court disorder is rampant, the influence of the Taoist sage becomes destructive, and the emperor has an ominous dream. In the meantime the Jürchen 'barbarians' become more and more obtrusive. In the end, the emperor abdicates and the Jürchen sack the capital. They begin 'moving out official records of the Imperial Academy, the Three Offices, and the Six Ministries, as well as census maps for administering the empire. ${ }^{35}$

Among the many interesting elements in this novel, apart from the escapades of the emperor, is the prominent role of the ministers in the process of decay. This role is emphasized not only by the distribution of the characters over the various factions, but also by inserting the literal texts of memorials submitted by officials to the emperor to explicate their opinion and to advise or correct him. There is, for instance, a memorial against the policy of Cai Jing, the protégé of Wang Anshi, who is depicted as the great villain of the story and the instigator of all evil. Also a memorial is included criticizing the lascivious

$\begin{array}{ll}32 & \text { Ibid., 62-63. } \\ 33 & \text { Ibid., 63. } \\ 34 & \text { Ibid., 79. } \\ 35 & \text { Ibid., 12O. }\end{array}$


excursions of the emperor, warning him against depravation and the ruin of the empire. The memorial is surprisingly explicit, qualifying Li Shishi as an 'ignoble whore' and her residence a 'brothel. ${ }^{36}$ When the emperor fails to heed this advice, he is admonished again: 'You are disrupting the regimen of the court and neglecting the administration of the government, while bandits act freely.' ${ }^{37}$ And: 'Only when men have degraded themselves can others degrade them. ${ }^{38}$

These inserted texts are not only meant to give the narrative a more realistic, historically faithful appearance; they are also included to illustrate the importance of the ministers in the process of government and to emphasize their responsibility within the administrative apparatus. They have a role that is to some extent objectively linked to the institutions and not to the emperor as a person. Thus, from the perspective of their 'objective' task, it is their duty to summon the emperor to mend his ways. Before warning the emperor of the dangers of his lasciviousness, one of his ministers reflects: 'Mencius has said: "One whose responsibility is to give advice should resign if he is unable to give it, even if it meant discountenancing the emperor." 39 The minister should provide the ruler with good advice, even at the cost of his life, or else resign. Therefore, in this text, too, a form of dialogism is constructed, which, on the one hand, regulates the relationship between fictional and 'real' components and, on the other hand, facilitates the configuration of good and evil forces. And, finally, this device makes possible the amalgamation of the story with the wisdom of statecraft, displaying its principles within a fictional setting.

\section{Concluding Remarks}

The narratives discussed above are not joined together in one chapter in order to argue that they are in some way or another historically linked. As observed in the introduction, such an effort would be beyond the scope of secure and sound argumentation. It is not without significance, however, that similar themes, motifs, and narrative procedures became popular within distinct cultural and historical contexts: European, Persian/Arabic, and Chinese. It would seem that the concept of kingship evokes similar associations in diverse societies and that

$\begin{array}{ll}36 & \text { Ibid., 73. } \\ 37 & \text { Ibid., 78. } \\ 38 & \text { Ibid. } \\ 39 & \text { Ibid., 73. }\end{array}$


similar techniques were deemed appropriate to explore them. Perhaps the similarities are due not to any kind of essentialized archetype of kingship or to an ultimately identical process of developing ideas about it, but rather to the relationship between power and texts, and the way in which texts function to structure discourses of authority. For the moment, it is important to draw attention to some motifs and procedures that we will encounter more frequently in our discussion of other textual types below.

The motifs that are central in the narratives above and that to a large extent determine their characteristics include, first, the motif of rupture and discontinuation of the dynasty, as a result of either the loss of the heir to the throne or the careless behaviour of the king. The end of the dynasty imposes the necessity to reformulate the essentials and principles of kingship, so as to re-establish the empire on its proper foundations. Thus, within a text, it allows the combination of a fictional intrigue with a reiteration of wisdom, represented in either fictional or non-fictional form.

Second, the crucial role of the ministers shows that the authority of the king is not monolithic or vested in the person of the king alone, or at least that it is embedded in a wider discursive environment. The king may embody power, quite literally, but this power is derived from a context that is (also) vested in institutions, discursive systems, and other participants. It is not merely that the power of the king is mainly symbolic and that for the implementation of his decrees he is dependent on others; it is rather that the relationship between power and authority is ultimately established by a dialogic process. As we will see in other cases, too, this is a paradox at the centre of the construction of kingship: The king embodies sovereignty, and in this condition he enjoys absolute power, but because he is all-powerful, he is not capable of doing anything he might wish. In order to fulfil his function as the locus of power effectively and harmoniously, his power has to be limited by the intervention of ministers, institutionalized procedures, and discursive frameworks, so that the forces of power are transformed into authority, which is not solely dependent on the use of violence.

Third, the threats to the empire are in all four cases caused by moral depravity, emotional impulsiveness, and irrationality. These adverse tendencies are systematically related to the disastrous interventions of women. If kings represent the power of the state, women represent power of a different kind, not based on 'objective' institutions, but on emotions, the senses, and subjective human impulses, which are inherently destructive. The drama takes place at the interface of these kinds of power, and the result should be that the king's power is in the end transformed into regular authority while the concubine's power is annihilated morally, physically, and discursively. In this 
misogynous scenario, women represent desire, loss of control, vulnerability, emotional blackmail, irresponsibility, pleasure, craftiness, immorality, jealousy, all characteristics irreconcilable with rationality and social harmony. And rationality is the crucial principle on which the state is founded and on which its survival depends.

These three elements are the basic ingredients for a dramatic enactment constructed by using different layers of texts. This hybridity is achieved either by playing with narrative levels within a narrative frame or by combining historical narrative-including realistic effects-with fictional narrative. As said above, this procedure is first of all meant to create a multiple perspective on the intrigue, which makes an interpretation of a given situation possible and at the same time lays bare the process of interpretation. It is this procedure from which these texts derive their force as part of discourses of power: They show what they represent; they embody the process that they reveal: how power is rationalized to become institutionalized in a form of authority. They both represent and enact the process of discursive formation. Fictionality is an indispensable part of this process, since it represents and reveals the link between the abstract, discursive, level and perceived reality.

The main problem that is elaborated in the texts is how the institutionalized power of the king is related to the power of a specific king in a specific situation. The general dilemma is perhaps best exemplified by the Chinese case. In Han Feizi's philosophy the emperor is both the 'absent' centre of a depersonalized, objective, structure of power, which is basically an apparatus meant to integrate procedures. Power is objectified in institutions, functions, and formal procedures as the organizational centre from which harmony and equilibrium radiate over society. Simultaneously, it is the emperor in whom the forces of Yin and Yang manifest themselves, and it is his behaviour that determines the functioning of the system. Thus, power is both personal and impersonal; the emperor both embodies power and situates it outside himself. Especially the novel Proclaiming harmony shows how this apparent contradiction imposes itself on history and how specific events bring up the problem of the two manifestations of power. In the case of the Seven viziers the situation is less abstract: The king is inclined to use his power in his guise as a human being, and in fact he is supposed to show his anger as a sign of his power, but he is alerted in time to the fact that he should take on his guise as a king bound by institutions and principles sanctioned by tradition and, especially, by the principle of sound judgement and rationality.

The choice of rupture as the main catalyst of the discourse of kingship is, of course, no coincidence. If there is one underlying concern that has inspired the texts analysed in this chapter, it is the necessity of continuity. 
The harmony, prosperity, and well-being of society lies in the continuation of what has been accumulated and elaborated within history and tradition, and the development of rational principles. As the narrator of Proclaiming harmony sighs when he describes emperor Huizong: 'He has destroyed the world of his ancestors. [...] Never did it occur to him how difficult it had been for his forebears to build their empire. ${ }^{\prime 0}$ It is here that the centrality of women becomes clear: within the fictional element they are represented not only as a source of disruption of the objective order, but also as a precondition of continuity and reproduction, with their connotations of subjectivity.

$40 \quad$ Ibid., 7 . 